\title{
RESEARCH ON ZINC BLOOD LEVELS AND NUTRITIONAL STATUS IN ADOLESCENTS WITH AUTOIMMUNE HEPATITIS*
}

\author{
Thalita Cremonesi PEREIRA ${ }^{1}$, Margareth L. G. SARON ${ }^{1}$, Wagner Alves de CARVALHO ${ }^{2}$, \\ Maria Marluce VILELA ${ }^{3}$, Nelci Fenalti HOEHR ${ }^{3}$ and Gabriel HESSEL ${ }^{3}$
}

\begin{abstract}
Context - Zinc deficiency in children and adolescents impairs their growing, development and immune system. Objectives - To verify the existence of plasma and leukocyte zinc deficiency in adolescents with autoimmune hepatitis. Methods - The study comprised 23 patients with autoimmune hepatitis, aged 10-18 years, assisted at the Ambulatory Service of Pediatric Hepatology of the University of Campinas Teaching Hospital, Campinas, SP, Brazil, and adolescents with ages compatible with the patients' ages comprised the control group. Sample of blood in both groups was collected for the analyses of plasma zinc and leukocyte zinc by atomic absorption spectrophotometry, beyond the nutritional status was evaluated in each adolescent. The following statistical tests were used: MannWhitney, Spearman's correlation and interclass concordance analysis. Results - The significance level adopted was 5\%. The average zinc level in plasma in patients was $71.91 \pm 11.79 \mu \mathrm{g} / \mathrm{dL}$ and, in the control group, it was $80.74 \pm 10.92 \mu \mathrm{g} / \mathrm{dL}$, showing a significant difference $(P=0.04)$. The leukocyte zinc level in patients was $222.33 \pm 166.13 \mathrm{pmol} / 10^{6} \mathrm{cells}$ and, in the control group, it was 226.64 $\pm 217.81 \mathrm{pmol} / 10^{6}$ cells; there was no statistical significance between them $(P=0.45)$. Conclusion - The evaluation of the nutritional status showed that eutrophy is prevalent in patients, and they presented a higher body fat value than the control group, with a significant difference. More research is needed with adolescents with autoimmune hepatitis regarding levels of essential micronutrients, such as zinc, because a good nutritional status can improve the prognostic of liver disease.
\end{abstract}

HEADINGS - Hepatitis autoimmune. Zinc deficiency. Nutritional status. Adolescent. Child.

\section{INTRODUCTION}

Autoimmune hepatitis (AIH) is a rare disease, with an annual incidence rate of 0.85 cases per 100,000 inhabitants. Affecting children and adults, its prevalence is greater in age groups from 10-20 and 45-70 years old. Seventy-five percent of the cases are women ${ }^{3,}$ ${ }^{22)}$. It is a chronic inflammatory disease of unknown etiology, presenting itself in more than half of the cases with signs and symptoms resembling those of acute viral hepatitis (jaundice, choluria, anorexia). In other patients, its presentation is very variable; sometimes it appears in an insidious way, other times by signs of portal hypertension, and more rarely by acute liver insufficiency ${ }^{(7)}$.

AIH is classified into three types, according to the presence of non-organ-specific auto antibodies. It is called type $1 \mathrm{AIH}$ when anti-smooth muscle antibodies, mainly of the antiactine and/or antinuclear types, are found. In type $2 \mathrm{AIH}$, anti-liver-kidney microsomal antibody is found ${ }^{(10,11)}$. Type $3 \mathrm{AIH}$ is rare, prevalent in women between 20 and 40 years old, featuring the presence of autoantibody to soluble liver-pancreas ${ }^{(21)}$.

The treatment for this disease is based on immunosuppresion by using prednisone and azathioprine at the respective doses of $1-2 \mathrm{mg} / \mathrm{kg} /$ day (maximum $60 \mathrm{mg} /$ day) and $1-2 \mathrm{mg} / \mathrm{kg} /$ day (maximum $75 \mathrm{mg} /$ day). The ministration scheme consists of high doses in the beginning of the treatment, with reduction every 2 months or according to the evolution of the laboratory exams ${ }^{(18)}$.

Maintenance of the nutritional state of AIH patients is important for a better prognosis, especially in patients who will undergo a liver transplant. In the pediatric age group, patients are going through a phase of weight gain, growth and bone formation. However, there are few researches about these parameters in such patients without a study about the specific nutritional deficiencies, such as oligoelements like zinc $(\mathrm{Zn})^{(1,4)}$.

$\mathrm{Zn}$ is an essential mineral that is active in several body functions, once it acts as a cofactor for more than 300 enzymes and proteins. It is important in the

\footnotetext{
* Study carried out in Center for Investigation in Pediatrics, State University of Campinas Medical School - FCM-UNICAMP, Campinas, SP, Brazil. This article has no conflict of interest. This work was supported by the State of São Paulo Research Foundation (FAPESP) and the Coordination for Higher Level Graduates Improvement (CAPES) and approved by the Research Ethics Committee of FCM-UNICAMP, under the protocol no. 676/2005

1 Postgraduate Course in Child and Adolescent Health, Pediatrics Department FCM-UNICAMP); ${ }^{2}$ Chemistry Department, Pontifical Catholic University of Campinas; ${ }^{3}$ Pediatrics Department FCM-UNICAMP), Campinas, SP, Brazil.

Correspondence: Dr. Thalita Cremonesi Pereira - Avenida Papa Pio XII, 135 - apt. 44 - Jardim Chapadão - 13070-091 - Campinas, SP, Brasil. E-mail: thalitapereira@yahoo.com.br
} 
activities of the immune system by preventing the formation of free radicals, in stature growth, sexual and cognitive development and DNA synthesis ${ }^{(5,23)}$. This mineral is found in great quantities in products of animal origin and seafood, mainly in red meat, shellfish, oyster, liver, viscera, and eggs. Daily $\mathrm{Zn}$ consumption for healthy individuals varies according to age, for children and adolescents between 1 and 18 years old, it varies from 3 to $11 \mathrm{mg} / \mathrm{day}^{(12)}$.

Signs and clinical symptoms of $\mathrm{Zn}$ deficiency include growth delay, hypogonadism, decreased appetite and hypogeusia, decreased cognitive functions, enteropathic acrodermatitis, alopecia, diarrhea, skin rash and immunodeficiency ${ }^{(23)}$. The specialized literature reports difficulty in establishing a trusted indicator to determine $\mathrm{Zn}$ deficiency, despite the difficulty of its method of analysis, some studies have affirmed that leukocyte $\mathrm{Zn}$ is the most trustworthy biomarker ${ }^{(2,8)}$.

Studies that evaluate $\mathrm{Zn}$ level in children and adolescent carriers of chronic liver diseases are scarce. There are no conclusive studies for certain diseases, such as autoimmune hepatitis; however, according to the recent literature, it seems that children and adolescents with chronic liver diseases present a tendency for $\mathrm{Zn}$ deficiency, since $42 \%$ of this population was diagnosed with lack of this chemical element ${ }^{(16)}$. That is why the aim of the present study was to verify the existence of plasma or leukocyte $\mathrm{Zn}$ deficiency in AIH adolescents.

\section{METHODS}

This study comprised male and female AIH patients aged 10-18 years old attending the Pediatric Hepatology Ambulatory Service of the University of Campinas Teaching Hospital (HC-UNICAMP), from January 2007 to March 2008. The control group consisted of apparently healthy individuals paired with the patient group according to age. The participants' parents or legal guardians signed the free informed consent form.

After at least 8 hours of fasting, adolescents had their blood collected and, on the same day, anthropometric data were obtained.

Plasma $\mathrm{Zn}$ was determined by the Biochemistry Laboratory of the UNICAMP Teaching Hospital, and the leukocyte $\mathrm{Zn}$ analysis was carried out by the researcher. The method of atomic absorption spectrophotometry was used in both procedures, and they followed standard literature methods ${ }^{(2,9)}$. The normality value of plasma $\mathrm{Zn}$ used was the one adopted by the UNICAMP Teaching Hospital, varying between 80 and $120 \mu \mathrm{g} / \mathrm{dL}$. Since leukocyte $\mathrm{Zn}$ does not yet present a normality value stipulated by epidemiological studies, the result was compared with the control group.

The measurement technique based on the method standardized by Lohman et al. ${ }^{(13)}$ was used for collecting weight, height, tricipital cutaneous fold and subscapular cutaneous fold. The percentage of body fat was obtained by the equation of Slaughter et al. ${ }^{(2)}$. The body mass index (BMI), height-for-age z-score (H/A), weight-for-height z-score (W/H) and weight-for-age z-score (W/A) was classified according to international reference data ${ }^{(14,15,24)}$.
Statistical data were processed using SPSS (Statistical Package for Social Science) version 7.5 for Windows. MannWhitney's U test was used to compare data of the patient group with those of the control group. Spearman's rank correlation was also used to verify the existence of correlation between the variables. The data considered significant for significance analysis were those with $P<0.05$.

\section{RESULTS}

This study comprised $23 \mathrm{AIH}$ patients, 17 females and 6 males, with average age of $12.93 \pm 1.98$ years. In the patient group, 17 patients were diagnosed with type $1 \mathrm{AIH}$, 2 patients with type 2, and 4 patients were AIH without classification.

The results of plasma and leukocyte $\mathrm{Zn}$ analysis are shown in Table 1. The average $\mathrm{Zn}$ level in plasma $(\mu \mathrm{g} / \mathrm{dL})$ in the patient group was $71.91 \pm 11.79$ and, in the control group, $80.74 \pm$ 10.92 , demonstrating a statistically significant difference $(P$ $=0.04)$. The average $\mathrm{Zn}$ levels in leukocytes ( $\mathrm{pmol} / 10^{6}$ cells) in the patient group was $222.33 \pm 166.13$ and, in the control group, $226.64 \pm 217.81$, demonstrating a non-significant difference $(P=0.45)$. There was no correlation between plasma $\mathrm{Zn}$ and leukocyte $\mathrm{Zn}$ levels $(P=0.29)$.

TABLE 1. Average, standard deviation and significance analysis $(P)$ of plasma $\mathrm{Zn}$ and leukocyte $\mathrm{Zn}$ of the patient group with AIH and the control group

\begin{tabular}{lccc}
\hline \multirow{2}{*}{ Variable } & \multicolumn{2}{c}{$\begin{array}{c}\text { Average and } \\
\text { standard deviation }\end{array}$} & \multirow{2}{*}{$\boldsymbol{P}$} \\
\cline { 2 - 3 } & $(\mathrm{n}=23)$ & $(\mathrm{n}=23)$ & \\
\hline \multirow{2}{*}{ Plasma $\mathrm{Zn}(\mu \mathrm{g} / \mathrm{dL})$} & $71.91 \pm 11.79$ & $80.74 \pm 10.92$ & $0.04^{*}$ \\
Leukocyte $\mathrm{Zn}\left(\mathrm{pmol} / 10^{6}\right.$ cells $)$ & $222.33 \pm$ & $226.64 \pm$ & 0.45 \\
& 166.13 & 217.81 & \\
\hline
\end{tabular}

$* P<0.05$ : statistically significant difference between the patient group and the control group

Regarding normality values adopted, $65.2 \%(n=15)$ of the adolescents with AIH presented plasma Zn deficiency.

Data of four patients who presented edema were not considered for evaluation of anthropometric indexes so as to prevent the results from being overestimated. For this reason, the patient group had 19 patients, and the control group still had 23 individuals for those indexes.

The BMI had an average $21.93 \pm 5.30 \mathrm{~kg} / \mathrm{m}^{2}$ in the patient group and $18.65 \pm 2.53 \mathrm{~kg} / \mathrm{m}^{2}$ in the control group, demonstrating statistical significance, with $P=0.02$. Classifying the patients' BMI according to age, it was verified that $68.4 \%$ $(n=13)$ of them had eutrophy, and $31.6 \%(n=6)$ were obese. No patient had malnutrition in relation to the BMI. Body fat percentage was $25.77 \% \pm 9.47 \%$ for the patient group and $18.99 \% \pm 6.40 \%$ for the control group, demonstrating statistical significance $(P=0.01)$.

Most patients were in a state of eutrophy for $\mathrm{W} / \mathrm{H}(73.7 \%)$, W/A $(89.4 \%)$ and H/A (87.0\%). Only $5.3 \%$ of the patients were classified as obese according to the W/A index and, for the $\mathrm{W} / \mathrm{H}$ index, the frequency of obesity was $26.3 \%$. Acute 
malnutrition was not present according to the $\mathrm{W} / \mathrm{H}$ index; however, according to the W/A index, one case was diagnosed and, for the H/A, two cases of chronic malnutrition with stature growth deficit were diagnosed.

There was no correlation between any indicators of nutritional state and plasma or leukocyte $\mathrm{Zn}$ levels.

\section{DISCUSSION}

The importance of studies about $\mathrm{Zn}$ status in humans, mainly in children and adolescents, is emphasized in the literature due to the countless body activities in which $\mathrm{Zn}$ takes part, especially promoting enzymatic reactions related to the growth and development of children and adolescents. Researches currently underway have highlighted how difficult it is to find a safe indicator to determine $\mathrm{Zn}$ deficiency in humans ${ }^{(8,23)}$. The difficulty in finding trusted $\mathrm{Zn}$ deficiency indicators was equally observed in the present study. While it was noticed plasma $\mathrm{Zn}$ deficiency, leukocyte $\mathrm{Zn}$ deficiency was not noticed in AIH adolescents when the average of these indicators was checked against that of the control group. Furthermore, the two $\mathrm{Zn}$ level indicators had no correlation between themselves. The same absence of correlation was observed by Goode et al. ${ }^{(6)}$, who studied leukocyte and plasma $\mathrm{Zn}$ levels in 13 adults with alcoholic cirrhosis and 17 with nonalcoholic cirrhosis, and verified that the plasma $\mathrm{Zn}$ level was low in both groups, whereas leukocyte $\mathrm{Zn}$ was normal when compared with the control group.
Schneider et al. ${ }^{(19)}$ evaluated plasma Zn concentration in 31 children and adolescents with cirrhosis ( 9 of them with AIH), and found $42 \%$ of the patients with plasma $\mathrm{Zn}$ deficiency, occurring a positive correlation between the gravity of the disease and the presence of cholestasis. It was observed that the frequency of plasma $\mathrm{Zn}$ in the present patients $(62.2 \%)$ was greater than in the cited study. This can suggest that $\mathrm{AIH}$ patients are more prone to $\mathrm{Zn}$ deficiency than patients with other diagnoses of chronic liver diseases.

Ferreira et al. ${ }^{(4)}$ observed that children and adolescents with $\mathrm{AIH}$ presented a significant reduction in the $\mathrm{H} / \mathrm{A}$ z-score. However, Porta ${ }^{(17)}$ did not find weight or height differences in children with $\mathrm{AIH}$ and Bellomo-Brandão et al. ${ }^{(1)}$ did not observe low stature in patients with type 1 and type $2 \mathrm{AIH}$. The present study agrees with the two last cited researches, since only two patients presented an $\mathrm{H} / \mathrm{A}$ z-score below -2, being then classified as bearers of chronic malnutrition with growth delay.

More research is needed with adolescents or children with autoimmune hepatitis regarding levels of essential micronutrients, such as $\mathrm{Zn}$, so as to evaluate the need for nutrient supplements for the patients. A good nutritional status and an adequate energy and nutrient intake act together with the medication to combat liver disease and avoid harm to the growth and development of children and adolescents. That is why it is very important to monitor periodically the nutritional status and the dietary intake of the patients throughout the ambulatory and hospital treatment.

Pereira TC, Saron MLG, Carvalho WA, Vilela MM, Hoehr NF, Hessel G. Investigação do nível de zinco sanguíneo e estado nutricional em adolescentes com hepatite autoimune. Arq Gastroenterol. 2011;48(1):62-5.

RESUMO - Contexto - A deficiência de zinco em crianças ou adolescentes acarreta danos ao crescimento, desenvolvimento e ao sistema imune dos indivíduos. Objetivo - Verificar a existência de deficiência de zinco plasmático e/ou leucocitário em adolescentes com hepatite autoimune. Métodos Participaram do estudo 23 pacientes com hepatite autoimune entre 10 e 18 anos, atendidos no Ambulatório de Hepatologia Pediátrica do Hospital de Clínicas da UNICAMP - Campinas, SP e 23 adolescentes com idade pareada com os pacientes formaram o grupo controle. Foi coletada amostra de sangue de todos os pacientes e grupo controle para as análises de zinco plasmático e zinco leucocitário por meio da espectrofotometria de absorção atômica, além de ter sido verificado o estado nutricional de cada adolescente. Os testes estatísticos empregados foram o de Mann-Whitney, correlação de Spearman e análise de concordância interclasses. Resultados - O nível de significância adotado foi de 5\%. A média de zinco plasmático nos pacientes foi de $71.91 \pm 11.79 \mu \mathrm{g} / \mathrm{dL}$ e no grupo controle foi de $80.74 \pm 10.92 \mu \mathrm{g} / \mathrm{dL}$, essa diferença foi significante $(P=0.04)$. O nível de zinco leucocitário nos pacientes foi igual a $222.33 \pm 166.13$ pmol/106 células e no grupo controle foi de $226.64 \pm 217.81$ pmol/10 células, não ocorrendo diferença estatisticamente significante entre estes $(P=0.45)$. Conclusão - A avaliação do estado nutricional mostrou que a eutrofia é prevalente nos pacientes e estes possuem maior valor de gordura corporal que o grupo controle com diferença significativa. São necessárias mais pesquisas com adolescentes com hepatite autoimune em relação aos níveis de micronutrientes essenciais, como o zinco, pois um bom estado nutricional pode melhorar o prognóstico da doença hepática.

DESCRITORES - Hepatite autoimune. Deficiência de zinco. Estado nutricional. Adolescente. Crianças.

\section{REFERENCES}

1. Bellomo-Brandão MA, Costa-Pinto EA, De Tommaso AM, Hessel G. Clinical and biochemical features of autoimmune hepatitis in 36 pediatric patients. Arq Gastroenterol. 2006;43:45-9.

2. Caticha O, Norato DY, Tambascia MA, Santana A, Stephanou A, Sarlis NJ. Total body zinc depletion and its relationship to the development of hyperprolactinemia in chronic renal insufficiency. J Endocrinol Invest. 1996;19:441-8.

3. Cowling DC, Mackay IR, Taft LI. Lupoid hepatitis. Lancet. 1956;271:1323-6.
4. Ferreira AR, Roquete ML, Penna FJ, Toppa NH. [Autoimmune hepatitis in children and adolescents: clinical study, diagnosis and therapeutic response]. J Pediatr. 2002;78:309-14.

5. Gibson RS. Assessment of trace-element status. In: Gibson RS. Principles of nutritional assessment. New York: Oxford University Press; 1990. p.511-53.

6. Goode HF, Kelleher J, Walker BE. Relation between zinc status and hepatic functional reserve in patients with liver disease. Gut. 1990;31:694-7.

7. Gregorio GV, Portmann B, Reid F, Donaldson PT, Doherty DG, McCartney M, Mowat AP, Vergani D, Mieli-Vergani G. Autoimmune hepatitis in childhood: a 20 years experience. Hepatology. 1997;25:541-7. 
8. Hambidge M. Biomarkers of trace mineral intake and status. J Nutr. 2003;133 (Suppl 3):948-55

9. Hinks LJ, Colmsee M, Delves HT. Determination of zinc and copper in isolated leucocytes. Analyst. 1982;107:815-23.

10. Homberg JC, Abuaf N, Bernard O, Islam S, Alvarez F, Khalil SH, Poupon R, Dainrs F, Lévy VG, Grippon P, Opolon P, Bernuau J, Benhamou JP, Alagille D. Chronic active hepatitis associated with antiliver/kidney microsome antibody type 1: a second type of "autoimmune" hepatitis. Hepatology. 1987;7:1333-9.

11. Houtkooper LB, Going SB, Lohman TG, Roche AF, Van Loan M. Bioelectrical impedance estimation of fat-free body mass in children and youth: a cross-validation study. J Appl Physiol. 1992;72:366-73.

12. Institute of Medicine. National Academy of Sciences on Dietary Reference Intakes (DRIs) - Dietary reference intakes for vitamin A, vitamin K, arsenic, boron, chromium, copper, iodine, iron, manganese, molybdenum, nickel, silicon, vanadium, and zinc. Washington: National Academy Press; 2002. p. $442-501$.

13. Lohman T, Roche A, Martorell R. Anthropometric standardization manual. Champaign: Human Kinetics Book; 1988. 177p.

14. Must A, Dallal GE, Dietz WH. Reference data for obesity: 85 th and 95 th percentiles of body mass index (wt/ht2) and triceps skinfold thickness. Am J Clin Nutr. 1991;53:839-46.

15. National Center for Health Statistics - 2000. Centers for Disease Control and Prevention [online]. Growth charts [cited 2009 Jan 28]. Available from: http:// www.cdc.gov/growthcharts.

16. Pereira TC, Hessel G. Deficiência de zinco em crianças e adolescentes com doenças hepáticas crônicas. Rev Paul Pediatr. 2009;27:322-8.
17. Porta G. Hepatite auto-imune na infância. Análise clínico-laboratorial, histológica e evolutiva [tese]. São Paulo: Universidade de São Paulo; 1993.

18. Porta G. Hepatite auto-imune. In: Ferreira CT, de Carvalho E, Silva LR, editores. Gastroenterologia e hepatologia em pediatria: diagnóstico e tratamento. Rio de Janeiro: Editora Médica e Científica; 2003. p.573-80.

19. Schneider ACR, Pinto RB, Froehlich PE, Borges AP, Maldonado A, da Silveira TR. Zinco plasmático em crianças e adolescentes com cirrose. Resumos do XII Congresso Brasileiro de Gastroenterologia Pediátrica e II Congresso Brasileiro de Hepatologia Pediátrica; 2005 nov 5-9; Gramado, RS, Brasil. p.16.

20. Slaughter MH, Lohman TG, Boileau RA, Horswill CA, Stillman RJ, Van Loan MD, Bemben DA. Skinfold equations for estimation of body fatness in children and youth. Hum Biol. 1988;60:709-23.

21. Strassburg CP, Manss MP. Auto antibodies and auto antigens in autoimmune hepatitis. Semin Liver Dis. 2002;22:339-52.

22. Werner M, Prytz H, Ohlsson B, Almer S, Bjornsson E, Bergquist A, Wallersted S, Sandberg-Gertzén H, Hultcrantz R, Sangfelt P, Weiland O, Danielsson A. Epidemiology and the initial presentation of autoimmune hepatitis in Sweden: a nationwide study. Scand J Gastroenterol. 2008;43:1232-40.

23. Wood RJ. Assessment of marginal zinc status in humans. J Nutr. 2000;130(5S Suppl):1350-4.

24. World Health Organization - WHO - 2007. Growth reference 5-19 years [cited 2009 Jan 28]. Available from: http://www.who.int/growthref/who2007_height_for_age/ en/index.html.

Received 11/8/2010 Accepted 21/9/2010 